\title{
ADAPTING TO ELECTORAL SYSTEM CHANGE \\ Voters in Lesotho, 2002
}

\author{
By \\ Roddy Fox and Roger Southall \\ Roddy Fox is Professor of Geography, \\ Rhodes University, Grahamstown 6140 South Africa. \\ Tel: +27046 603.8722; Fax: +27046 636.1199; e-mail: R.Fox@ru.ac.za \\ Roger Southall is Executive Director, Human Sciences Research Council, \\ Private Bag X41, Pretoria 0001South Africa. \\ Tel: +27 012 302.2261; Fax: +27 012 302.2216; e-mail: RSouthall@HSRC.ac.za
}

On 25 May 2002 voters in the small Southern African kingdom of Lesotho went to the polls in the third general election since the country returned to democracy after a long period of civilian dictatorship (1970-86) and military rule (1986-93). Although voting in all Lesotho's general elections has usually gone smoothly, in every case prior to 2002 the results have been challenged, with varying degrees of severity, by the losing parties (Weisfelder 1999, pp 109-32).

This occurred most notably in 1970, when the ruling Basotho National Party (BNP) lost the election but overrode the result; and subsequently in 1998, when the BNP - now in opposition - had been at the core of an alliance of electoral losers who, in the months that followed and enjoying the quiet support of the security forces, so paralysed the capital that a powerless government felt constrained to call for external assistance to restore order. The result was military intervention by South Africa and Botswana (acting on behalf of the Southern African Development Community (SADC)); the restoration of the ruling Lesotho Congress for Democracy (LCD) to power; and an extended period when, backed by South African muscle, long overdue reforms of the military and police were matched by difficult negotiations among the various political parties concerning the adoption of a new electoral system. The eventual outcome was the decision to move Lesotho away from the plurality (first-past-the-post) system inherited from Britain at independence (and which in 1993 and 1998 had provided highly imbalanced results favouring the winning party) towards a Mixed Member Proportional (MMP) system.

Hence, the 2002 election assumed a significance that extended well beyond Lesotho's borders. On the one hand, just two months after the authoritarian regime in Zimbabwe had rigged the re-election of Robert Mugabe in that country's presidential election, there was considerable interest in whether a reformed electoral system could provide a basis for free, fair, and peaceful elections in another Southern African country where results had customarily been bitterly disputed. In short, democracy in the region badly needed an indisputably legitimate poll. On the other 
hand, Lesotho was the first country on the continent to move to MMP at a time when discussion of electoral system change was becoming widespread throughout Africa.

The particular issue in Lesotho in 2002 was not merely whether MMP would provide an improved basis for electoral legitimacy and political stability. That was clearly the prime question, and the fairly unambiguous answer that has been given by events has been 'yes'. Yet there was also an important subsidiary question concerning practicality and voters' understanding. In other words, to what extent was it possible to explain a new voting system to an electorate in one of Africa's poorest countries? How could they be convinced that the new system would be fair? How would they tackle the fact that each voter would now have the opportunity to cast not just one, but two, votes?

The overall success of the election has been demonstrated elsewhere (Elklit 2002 pp 1-10; Southall 2003, pp 1-28). The purpose of the present short paper is to address the question about voters' understanding and to demonstrate their ability to adapt to electoral system change. This, we suggest, throws doubt on any argument that electoral reforms in Africa should be avoided on grounds of the alleged lack of sophistication of poor and largely uneducated voters. Ordinary people appear to have no huge difficulty understanding the broad principles of electoral democracy, even if the detailed mechanics of 'mixed' voting systems may be beyond them.

\section{BACKGROUND To LesOtho's Adoption OF MMP}

After years in which its principal leaders had been in exile (following the BNP's overriding of the result of the election of 1970) the opposition Basutoland Congress Party (BCP) - led by the veteran nationalist Ntsu Mokhehle - secured a landslide victory of fully 65 seats to nil (with 75\% of the total votes) in the election of 1993. This amazing result, it is important to note, was gained in a poll which received massive endorsement from international and domestic electoral monitors as being free and fair. Apart from being an accurate reflection of voters' sentiments, the poll was at one level the outcome of an historical drama: the $\mathrm{BCP}$, the principal vehicle of anti-colonial militancy, was securing its just deserts in the form of victory at the polls, having been unjustly (as it argued) deprived of triumph in the preindependence general election of 1965 and then cheated outright in 1970.

The voters were not in a forgiving mood and, as much as they chose to celebrate the victory of Mokhehle and the BCP, they were also out to punish the BNP for long years of corrupt and dictatorial government (Southall and Petlane 1995). Yet, at another level, the particular result of the election was the product of Lesotho's unique political geography (the fairly consistent proportions of BCP majorities and BNP minorities being replicated in each and every constituency)(Fox 1995) combined with the mechanics of the plurality electoral system (which, as elsewhere, tended to award a disproportionate number of seats to the winning party). 
For the BNP, most notably, but also for a clutch of minor parties, the BCP's whitewash was not only devastating, it was wholly unbelievable, whatever the electoral monitors had to say. Yet worse was to follow, for after the failure of the BNP to force another election by backing a constitutional coup by the King in 1994 (which SADC demanded he reverse) ${ }^{1}$, the BNP suffered another trouncing in 1998.

In this latter year the electoral scene had become immensely complicated by a power struggle within the BCP. In brief, the aged Mokhehle had lost control of the party machinery yet had retained the support of a majority of members of parliament (MPs). He therefore wholly outmanoeuvred his intra-party opposition by leaving the party he had created, the $\mathrm{BCP}$, and forming the LCD, which, overnight, became the ruling party. Then, its leadership having been handed over to Pakalitha Mosisili, Mokhehle's chosen successor, the LCD proceeded to thrash all comers in the 1998 general election, taking 79 of the (now) 80 seats, albeit with just $61 \%$ of the votes cast (Southall and Fox 1998, pp 669-96). Despite winning a combined total of $40 \%$ of the votes, the opposition parties were again left without representation in the lower house of Parliament (even if they secured some compensatory seats by nomination in the relatively toothless Senate).

Although international monitors could yet again find no serious fault with the conduct of the election, the imbalanced result threw the country into turmoil. The principal opposition parties, the BNP and the rump BCP, forged a coalition of protest which drew wider support from other disappointed forces; and together they summoned their supporters to the capital, precipitating weeks of crisis which, when it appeared to be culminating in a decision by the military to stage a coup, resulted in armed intervention by South Africa and Botswana. Because this was initially badly bungled and opposition militants set much of the capital, Maseru, ablaze, South Africa in particular came in for widespread international ridicule and criticism, as well as considerable popular hostility within Lesotho (Southall 2001 pp 153-72). Nonetheless, in the weeks and months that followed, South African diplomacy manufactured a significant political achievement. The LCD was restored to power, but an Interim Political Authority, comprising all twelve political parties that had competed in the latest election, was constituted to consider a change in the electoral system, with the particular objective of finding a system that would provide for reasonable representation of the opposition. The negotiation process which followed was tortuous, and instead of the parties managing to find agreement to enable the holding of a fresh election in May 2001, the entire process was delayed by a year. Eventually, however, 'sufficient consensus' was reached, providing the basis for holding an election under a system of MMP in May 2002. The outcome of

Following the announcement of Prime Minister Mokhehle's decision to establish Commissions of Enquiry into the affairs of the monarchy and the army, the King - prompted by the BNP and secure in the knowledge of the support of the military - dismissed the LCD government on 17 August 1994 and announced the appointment of a provisional administration to lead the country to new elections. However, following intense pressure from the SADC 'troika' of South Africa, Zimbabwe and Botswana, he returned power to the LCD government at the end of September. See Matlosa 1995. 
that election was a further huge victory for the LCD, yet on this occasion the reformed system provided for the proportionate representation of the parties of opposition. And after initial rumblings of discontent, they accepted the result and took their seats in Parliament.

\section{Lesotho's New Electoral Model}

Lesotho, like the overwhelming majority of Britain's former colonies, had inherited a plurality electoral system. This provided for relatively competitive contests in the elections of 1965 and 1970, the BNP securing a narrow working majority in the former, yet losing by a substantial number of seats (9) in the 65-seat Parliament in $1970 .{ }^{2}$ (However, the working out of forces of 'modernisation's and a politically polarised history were to result in thoroughly imbalanced outcomes in 1993, when the BCP won by 65 seats to nil; and in 1998, when the successor LCD swept all but one of 80 constituency seats. Of course, the plurality system has what Elklit (2002, p 2) terms 'an in-built and intentional tendency to produce a result where the winner's share of the seats is higher (sometimes much higher) than its share of the votes', and hence tends to produce definite electoral winners rather than proportionality. Yet the Westminster model, which the plurality system serves, also conventionally produces a parliamentary opposition. However, when it fails to do so, as in the extreme cases of Lesotho in 1993 and 1998, the disadvantages of the plurality system, notably its lack of proportionality, become strikingly evident. ${ }^{4}$ Hence it was that that the IPA had been tasked with reviewing the electoral system to make it 'more democratic and representative' (Elklit, p 2).

The highly fractious negotiation process within the IPA has been detailed elsewhere (Southall 2003). Suffice it to say that, in broad terms, whereas the ruling LCD wished to maximise the number of constituency seats, the opposition rapidly swung to favouring relatively extreme forms of proportional representation. The eventual compromise saw all 80 existing constituency seats, to be elected by the plurality system, being retained, alongside the creation of 50 new, compensatory,

2 In 1965 the BNP secured 31 seats with $41.6 \%$ of the votes, compared to the BCP, with 25 seats and $39.6 \%$ of the votes. The electoral situation was reversed in 1970, with the BCP winning 36 seats with $49.8 \%$ of the votes, and the BNP 23 seats with 41.6\% (Southall and Petlane 1995, Appendix One).

3 In his analysis of changing electoral patterns over the course of the 1965, 1970 and 1993 elections, Fox (1995) identified the working out of a 'modernisation' variable which saw the influences of labour migrancy to South Africa and urbanisation inclining voters towards the more radical agenda of the BCP. Because most migrants were male, this 'modernisation' variable also had a gender dimension as well as a regional one in that the lowland areas (most immediately susceptible to South African economic impact) were more prone to vote $\mathrm{BCP}$ than the more conservative mountain areas.

4 To the authors' knowledge, the results in Lesotho in leaving the opposition completely unrepresented are unique, at least in Africa. In the 1960 pre-independence election in Tanganyika, the Tanganyika African National Union took all but one of the 71 African constituencies (11 and 10 seats being reserved separately for Asian and European voters respectively) (Tordoff 1967, p3). Of course, this imbalance in Tanganyika provided a major justification for President Julius Nyerere to lead the country towards a model of 'one party democracy'. 
seats to be elected by a national list system of proportional representation. Again, once the relative numbers of constituency and PR seats had been determined, the LCD had favoured a parallel electoral system whereby the 50 PR seats would be allocated according to the number of votes cast divided by 50 . In contrast, the opposition parties favoured the MMP system whereby the 50 PR seats would be allocated amongst parties, with PR being applied by total national list election votes cast divided by 130 to determine a quota per seat (which would favour the smaller contestants). ${ }^{5}$ The matter went to arbitration (as shrewdly provided for under the IPA Act of 1998) and the MMP system prevailed, albeit after considerable pressure exerted by the LCD had resulted in the reduction of the PR seats to just 40 . It was therefore an ' $80+40$ ' MMP model which was presented to the voters for the general election of 2002.

How was this to be done? The question was all the more pressing because, given the turbulence associated with past election outcomes, many voters were highly sceptical about the capacity of Lesotho's politicians to accept any electoral result which did not favour them.

\section{The Election And Its Outcome}

Lesotho is, of course, notorious for the extent of its economic dependence on South Africa (by which it is externally surrounded) and its financial dependence on development aid. During the 1970s and early 1980s Lesotho, under the BNP, had attracted international representation and aid by skilfully exploiting its image as an island of non-racialism, and - as well as serving as something of an operations base for the African National Congress (ANC) - had provided hospitality to South African refugees from apartheid. However, following the arrival of democracy in South Africa in 1994 Lesotho lost much of its political sex appeal and all but a handful of foreign countries removed their representation and redirected their aid to South Africa. Those that remained, although initially encouraged by the return to civilian rule and formal democracy in 1993, were thereafter to become increasingly disillusioned by the fractiousness of Lesotho's politicians and the unruly behaviour of its security forces. When the 1998 elections ended in mayhem and Maseru was, in large part, razed to the ground, what remained of the international 'donor community' was very tempted to all but abandon the country to its self-inflicted fate of disorder and underdevelopment. Hence, although the mode of South Africa's intervention in 1998 may have been criticised, its intention and subsequent diplomatic follow-through were welcomed. In the event, therefore, although they had become impatient with the political wrangling which had taken place within

\footnotetext{
The difference in outcome would have been significant. Using the 1998 voting figures, the MMP system would have led to the BNP obtaining 33 seats, the BCP 14, and other parties 3, with the LCD remaining restricted to 79 constituency seats. In contrast, the parallel system would have resulted in the LCD obtaining a total of 110 seats, the BNP 14, the BCP 5 and the Marema-Tlou Freedom Party 1 seat.
} 
the IPA, the donors were prepared, in effect, to underwrite the experiment with MMP and to give Lesotho 'one last chance'. The result was that the administration of the 2002 election received considerable international attention and aid, notably from the European Union (EU), the Commonwealth, Britain and the United States, with South Africa itself providing considerable logistical support.

Following the appointment of a completely new team to head the Independent Electoral Commission (IEC) enormous efforts were made to arrange for an electoral process that would offer minimal grounds for dispute.

First, on the basis of a registration process conducted in August and September 2001, a high-tech computerised voters' role was completed by January 2002. Voters, who were required to dip their fingers in indelible ink when registering, would only be able to vote upon presentation of a voter registration card which displayed their photo, fingerprint and signature (with indelible ink again being used at the actual polls).

Second, immense care was taken to involve the agents of political parties at all stages of the process, with party representatives sitting on eight IEC committees (concerning electoral law, security, and so on). In particular, the parties were employed alongside IEC officials in a concerted effort to explain the dual voting process (one vote for constituency MPs, one for a party in the PR election).

Third, and very importantly, ballot boxes were transparent.

Fourth, the dual voting process was carefully explained at the polling booths. It was evident to observers that the staff hired by the IEC from the local communities to run the polling booths had been extremely well trained. They were enormously patient in their explanations to voters of the mechanics of voting and would take great care to direct voters through each step of the process. Hence, after queuing (often for some hours!) to vote, individual voters would (i) have their identities checked; (ii) be provided with a voting slip for the constituency election which, after completion, they would drop into a constituency election ballot box; before (iii) being shepherded to receive their PR voting slip, which, after completion, they would deposit in a completely separate, PR election, ballot box. Finally, the EU financed an Election Results Centre, open to the leaders of political parties and registered election monitors and journalists, to which results were dispatched electronically from the constituencies after they had been announced locally. Additionally, of course, there was a heavy presence of election monitors throughout the country, drawn variously from SADC, the Commonwealth, the European Community and local non-governmental organisations.

The wisdom of Lesotho having adopted MMP became readily apparent when the initial results were announced, for the ruling LCD had again made a virtually clean sweep of the constituencies, taking 77 of the 78 seats contested on election day $^{6}$ with $57.7 \%$ of the vote (down from $60.5 \%$ in 1998). Meanwhile, it had taken a very similar proportion of the PR votes. Had the parallel method of calculating the

\footnotetext{
${ }^{6}$ Constituency elections were postponed in Mt Moorosi and Hlotse owing to the deaths of candidates.
} 
LCD's proportion of the PR seats been employed, it would have taken its 77 seats (plus the two seats it subsequently won in by-elections) plus 22 of the PR seats, or 101 of the total of 120 seats. In the event, however, following the allocation of seats under MMP, all 40 PR seats were allocated to opposition parties. ${ }^{7}$

\section{Results of the 2002 Lesotho General Election}

\begin{tabular}{|c|c|c|c|c|c|c|}
\hline PARTY & $\begin{array}{c}\text { TOTAL } \\
\text { CONSTITUENCY } \\
\text { VALID VOTE }\end{array}$ & $\begin{array}{l}\text { CONSTITU- } \\
\text { ENCY SEATS } \\
\text { WON }\end{array}$ & $\begin{array}{c}\text { TOTAL } \\
\text { PR VOTE }\end{array}$ & $\begin{array}{c}\text { PARTY'S } \\
\text { ALLOCATION } \\
\text { OF COM- } \\
\text { PENSATORY } \\
\text { PR SEATS }\end{array}$ & $\begin{array}{c}\text { PARTY'S } \\
\% \text { OF } \\
\text { VALID } \\
\text { CONS- } \\
\text { TITUENCY } \\
\text { VOTES }\end{array}$ & $\begin{array}{l}\text { PARTY'S } \\
\% \text { OF } \\
\text { VALID } \\
\text { PR } \\
\text { VOTES }\end{array}$ \\
\hline LCD & 305013 & 77 & 304316 & 0 & 55.65 & 54.89 \\
\hline BNP & 112707 & 0 & 124234 & 21 & 21.30 & 22.41 \\
\hline LPC & 32474 & 1 & 32046 & 4 & 6.14 & 5.78 \\
\hline BAC & 17103 & 0 & 16095 & 3 & 3.23 & 2.90 \\
\hline ВСР & 13658 & 0 & 15584 & 3 & 2.59 & 2.81 \\
\hline LWP & 7693 & 0 & 7788 & 1 & 1.43 & 1.40 \\
\hline MFP & 7475 & 0 & 6890 & 1 & 1.41 & 1.24 \\
\hline PFD & 6997 & 0 & 6330 & 1 & 1.32 & 1.14 \\
\hline NIP & 4258 & 0 & 30346 & 5 & 0.80 & 5.47 \\
\hline NPP & 4047 & 0 & 3985 & 1 & 0.76 & 0.71 \\
\hline * & 17671 & 0 & 7772 & 0 & 3.34 & 1.40 \\
\hline Valid & & & & & & \\
\hline Votes & 529096 & & 554386 & & & \\
\hline Invalid & 17618 & & 12063 & & & \\
\hline Votes & $(3.22 \%)$ & & $(2.12 \%)$ & & & \\
\hline Registered & 831315 & & & & & \\
\hline Voters & & & & & & \\
\hline
\end{tabular}

* Minor parties and Independents

Abbreviations:

LCD: Lesotho Congress for Democracy; BNP: Basotho National Party; LPC: Lesotho People's Congress; BAC: Basutoland African Congress; BCP: Basutoland Congress Party; LWP: Lesotho Workers' Party; MFP: Marema-Tlou Freedom Party; PFD: Patriotic Front for Democracy; NIP: National Independence Party; NPP: National People's Party. 
Given our particular interest in exploring how voters adapted to the new electoral system, what is most remarkable is the overall consistency of the voting pattern. Voters clearly had no difficulty in voting for a particular party candidate for the constituency contest and for the same party in the PR election. The only anomaly is the vastly better performance registered by the insignificant NIP in the PR contest (5.44\%) relative to its showing in the constituency elections $(0.76 \%)$. Yet this is easily explained, for the NIP had made a shrewd pre-election move by officially registering its party symbol (by which illiterate voters distinguish their parties on ballot forms) as a bird very similar to that of the ruling LCD! Despite the protests of the latter, the courts allowed the NIP's choice to stand, with outstanding results for its cunning.

Meanwhile, the small proportion of invalid votes (spoilt or indecipherable) was a testament to the efficacy of the voter education process, both before and during the poll. Given the fact that for the past forty years voters had been using the plurality model, it would have been reasonable to presume that there might have been some confusion with the party list/PR ballot. In practice, however, the opposite seems to have been the case. The number of votes declared invalid under the PR contest was fully one-third lower than in the constituency elections. Furthermore, the number of invalid constituency votes would have been higher if constituency contests had also been held on general election day in all 80 rather than only 78 of the constituencies. Indeed, only five of the 78 constituencies did not reflect this overall pattern, that is, they had more invalid PR votes than constituency votes.

Overall, therefore, the evidence demonstrates that Lesotho's voters had no difficulty adapting to the changed electoral system. Equally importantly, the process was so transparent and so well organised that when the BNP, on the basis of extremely thin evidence, declared that the result had been rigged, its attempt to have the result annulled so lacked credibility that, under only fairly light pressure from international donors, it fairly rapidly gave way and agreed to take its seats in Parliament. Lesotho had achieved far and away the most satisfactorily completed and most widely accepted general election in its tumultuous, post-colonial history.

\section{Lessons From LeSOTHO?}

The particular significance of the May 2002 general election in Lesotho is that electoral reform in Africa can be accomplished without undue difficulty. Indeed, Lesotho's poll may have a much wider resonance, initially, perhaps, in Eastern, Central and Southern Africa, but perhaps in time to come in the troubled countries of West Africa.

It is probably true to say that the transition to MMP in Lesotho was made a lot easier by the fact that South Africa had adopted PR for its first democratic election, in 1994. Prior to that, the racially separated elections for the tri-cameral (for whites, Indians and coloureds) national Parliament and the various African homelands 
had all been conducted under the plurality system. However, because of the complexities of undertaking a constituency demarcation and voter registration exercise and, more importantly, the emphasis placed by the transitional negotiations on securing adequate representation of political diversity, the plurality system had been abandoned in favour of a national list PR system. The result, not least because it was linked to the idea of a Government of National Unity (which included representation from the second and third largest parties alongside the victorious ANC), made a large impact throughout Africa, as it moved away from the practice of 'winner-takes-all', which has provided the basis for dictatorship in too many countries. The South African example therefore proved a stimulus to acceptance of change which eased Lesotho's own abandonment of first-past-the post.

It may now be said that Lesotho has returned the compliment of providing an example. Its own first MMP election occurred during the sitting of an Electoral Task Team (ETT), established in South Africa in terms of the 'final' Constitution promulgated in 1996, under which the electoral system was to be reviewed as long as any reform resulted, in general, in proportional representation. In general terms, the key issue for the ETT was whether it was desirable to re-introduce some form of constituency system so as to restore a direct link between the voters and (at least some of) South Africa's MPs. According to a survey commissioned by the Task Team voters were clear that, although they valued PR because of its representivity, the fact that MPs were only indirectly elected (by securing places on their party lists) adversely affected political accountability (Southall and Mattes 2002). In the event, the ETT presented a divided report to the government. All members agreed that the introduction of an amended electoral system for the speedily approaching election in 2004 would be unwise. However, while the majority favoured the introduction of some 80 multi-member constituencies which would elect 75 per cent of MPs (with 25 per cent being elected by party list in order to guarantee overall proportionality) for the projected elections in 2009, the minority favoured retaining the present system whereby all candidates are elected from party lists. In the event, the government chose to postpone the issue. While it agreed to put forward the Bill necessary to maintain the present electoral system for 2004, it decided that a further Bill, which would consider the electoral system suitable for the longer term, should be handled by Parliament after the next election. Significant commentary opined that this indecision reflected the ANC's own reluctance to change a system which has already served it so well. Nonetheless, some reintroduction of the idea of constituencies has been placed on the agenda, and Lesotho's modest example of how relatively easy it has been to combine constituency elections within an overall framework of PR has been widely noted.

Meanwhile, it is likely, too, that Lesotho's example will be cited as positive evidence in favour of electoral reform away from plurality systems in countries such as Kenya and Zimbabwe, both of which have seen the abuse of first-past-thepost to serve the regime in power (notably via imbalanced constituency demarcations favouring the ruling party) (see, eg, Fox 1996, pp 597-608). At long 
last, in Kenya, in the December 2002 general election, the opposition parties learnt the lessons of division by forming a Rainbow Alliance which swept the ruling Kenya African National Union government of President Daniel arap Moi away. A constitutional reform process, now taking place, will almost certainly choose to look in detail at alternatives to the plurality electoral system.

Meanwhile, in Zimbabwe, the dictatorship of Robert Mugabe seems destined to crumble and to make way for a process of democratic transition during which, again, the present opposition parties will probably want to explore electoral reform in pursuit of combining both fair political representation and the popular accountability of politicians. Then again, a major constitution-writing process is about to happen in the Democratic Republic of Congo and it may well be that civil society input (even if not that of political elites) will stress the drawbacks of untrammelled, national list PR. In short, tiny Lesotho may possibly have set the ball rolling towards the adoption of mixed electoral systems throughout the wider region.

In conclusion, however, it is necessary to temper any hasty euphoria about MMP with the recollection that its introduction in Lesotho was facilitated by exceptional conditions. Although it is extremely mountainous and hampered by poor internal communications, Lesotho is an easy country in which to conduct elections. As noted above, it has been the refusal of losing politicians to accept the results of elections, not the actual administration of elections, which has customarily been the problem there. Lesotho, after all, is a tiny country, with a tiny electorate to be registered, educated and counted. At election times it can be saturated with election monitors and observers in a way that a vast territory such as Nigeria cannot. Such factors were clearly highly favourable to the necessary training of electoral staff to facilitate the smooth introduction of the MMP electoral system.

Finally, it must be noted that only a handful of voters can be expected to understand the more complex calculations whereby compensatory PR seats can be allocated to the political parties. What is clearly important in this regard is that voters grasp the principle of proportionality provided for by MMP and that they trust the electoral body which undertakes the calculations. In Lesotho's case, the fact that the LCD was overwhelmingly the most popular party, and was unambiguously returned to power, was almost certainly a factor in the widespread acceptance of MMP.

None of this should detract from the minor triumph for democracy that the 2002 election in Lesotho represents. Yet we must sound a note of caution-although it provides a highly positive example, electoral reform might not be achieved quite so easily elsewhere. 


\section{$\longrightarrow$ REFERENCES}

Elklit, J. 2002. 'Lesotho 2002: Africa's first MMP Election'. Journal of African Elections $1(2)$.

Fox, R. 1995. 'Lesotho's Changing Electoral Geography, 1965-1993'. In R Southall and T Petlane. Democratisation and Demilitarisation in Lesotho: The General Election of 1993 and its Aftermath. Pretoria: Africa Institute.

_.1996. 'Bleak Future for Multi-Party Elections in Kenya'. The Journal of Modern African Studies 34(4).

Matlosa, K. 1995. 'The Military after the Election: Confronting the New Democracy'. In R Southall and T Petlane. 1995. Democratisation and Demilitarisation in Lesotho: The General Election of 1993 and its Aftermath. Pretoria: Africa Institute, pp 118-139.

Southall, R. 2001. 'SADC's Intervention into Lesotho: An Illegal Defence of Democracy?'. In Oliver Furley and Roy May (eds). African Interventionist States. Aldershot: Ashgate.

-2003. 'An Unlikely Success: South Africa and Lesotho's Election of 2002'. The Journal of Modern African Studies 41(2).

Southall R and T Petlane. 1995. Democratisation and Demilitarisation in Lesotho: The General Election of 1993 and its Aftermath. Pretoria: Africa Institute.

Southall R and R. Fox. 1998. 'Lesotho's General Election of 1998: Rigged or de rigeur?'. The Journal of Modern African Studies 37(4).

Southall R and R. Mattes. 2002. Popular Attitudes towards the South African Electoral System: Report to the Electoral Task Team. Pretoria: Human Sciences Research Council.

Tordoff, W. 1967. Government and Politics in Tanzania. Nairobi: East African Publishing House.

Weisfelder, R. 1999. 'Why fair elections get fouled in Lesotho: a search for solutions'. Journal of African Policy Studies 5(2\&3). 